\title{
THE CZECH LABOUR MARKET AFTER THE CRISIS OF A REAL ECONOMY: NEGATIVE DEVELOPMENT OR RETURN TO STEADY-STATE?
}

\author{
P. Tuleja, M. Tvrdoň
}

Received: May 30, 2011

\begin{abstract}
TULEJA, P., TVRDOŇ, M.: The Czech labour market after the crisis of a real economy: negative development or return to steady-state? Acta univ. agric. et silvic. Mendel. Brun., 2011, LIX, No. 7, pp. 477-488

This paper studies the Czech economy before, during and after the economic crisis. Consequences on the labour market, respectively on unemployment are also discussed in the paper. According to most economists the cause of the economic crisis was the financial crisis which was triggered by a liquidity shortfall in the United States banking system. It has resulted in the collapse of large financial institutions, the "bail out" of banks by national governments and downturns in stock markets around the world. Real gross domestic product decreased in almost all EU countries including the Czech economy. Massive drop of gross domestic product led to increase in the unemployment rate. The purpose of this paper is to contribute to discussion about consequences of this crisis. The paper provides also an analysis of gross domestic product and its components. The empirical analysis also tried to answer the question if it is more a return to steady-state than the deterioration of economic performance in the case of the Czech economy. In other words, it means that economic performance of the Czech economy was above the level of potential output. Research in this study is based on basic macroeconomic quarterly data between the years 2000 and 2010 which were published by the Czech Statistical Office and Eurostat. We found out that the Czech labour market had to cope with the consequences of the economic crisis and now it is going to reach a long-term equilibrium.
\end{abstract}

gross value added, gross domestic product, potential output, unemployment rate, natural rate of unemployment, Beveridge curve

The Czech economy can be characterized as a small open economy strongly dependent on foreign demand, especially German one. It generally displays a high degree of synchronization with other EU Member States. In the pre-crisis period, the Czech economy benefited from flourishing external demand shifting real GDP above its longterm potential. This dependence on foreign markets seems to be the main cause of macroeconomic vulnerability. According to PWC (2010) a limited internal market or high taxation burdens are other weaknesses of the Czech economy. On the other hand, high productivity and industrial competitiveness, high investment attractiveness and financial reliability, low government debt and low private debt or EU membership are the main strengths of the Czech economy.

It is well known that the financial crisis had its origins in the United States of America (U.S.). As the crisis unfolded in the U.S., a number of countries' real economies suffered from a decreased U.S. consumer demand, and credit problems arising from the U.S. mortgage sector rapidly have permeated across nations, ensnaring financial institutions worldwide (Fernández and NikolskoRzhevskyy, 2010). In the following months, problems of the financial sector gradually spilledover to the real economy and had dragged the world economy in the painful economic crisis. However, the influence of the world economic crisis on the convergence process is questionable (for 
more detailed analysis see Rozmahel, 2011). These dramatic changes in economic performance have been the subject of debate among renowned world and domestic economists. Although conclusions from this discussion are well known, there are also currently some areas without unambiguous conclusion, and the labour market is just one of those areas. It is widely accepted relationship between phases of the business cycle and the number of unemployed - if the economy achieves growth, the unemployment rate will decrease (with some delay). On the contrary, if the economy is hit by the recession, the unemployment rate tends to increase sharply. Thus, our fundamental question is: Has led the decline of economic performance followed by the rise in the unemployment rate to significant deterioration of labour market performance or simply the labour market is going to return to a state that could be called as a long-term equilibrium or steady-state?

The aim of this paper is to examine factors of the economic crisis in the Czech economy and its effects on the labour market during the period 2000-2010.

The paper is structured as follows. The next part deals with course of the economic crisis in the Czech Republic and its consequences. This chapter is based on descriptive economics and we used the standard macroeconomic indicators. Next part is focused on description of labour market performance and its development and the last section concludes our analysis.

\section{Influence of the crisis on performance of the Czech economy}

Looking at performance of the Czech economy for the past ten years, the Czech economy kept relatively good pace of growth between the years 2000-2010, although, according to our calculations, Czech gross domestic product (GDP), expressed in constant prices of the year 2000, grew annually by an average of $3.24 \%$. As the result, the volume of the Czech GDP increased by one third. According to Vintrová (2008) the main reasons of this development can be seen in accession into the EU and cultivation of the institutional framework which made the Czech Republic more attractive for foreign capital. Massive inflows of foreign direct investment have accelerated trade integration within the EU and promoted export-oriented economic growth.

Based on a simple analysis of Eurostat quarterly data, we identified two main periods during which significant changes in GDP occurred (see Figure 1):

- The first phase, which began in 1999 and ended in the third quarter of 2008. This period is characterised by overall growth in output (real GDP increased by $34.16 \%$ in total, $4.32 \%$ per year in average respectively. Economic growth constituted the primary source for more rapid catching-up process. The most significant quarterly growth rates of real GDP occurred in the time period between IQ 2005 to IQ 2007. Spěváček and Vintrová (2010) found that this significant growth was not accompanied by, unlike most New Member States, the deteriorating macroeconomic balances.

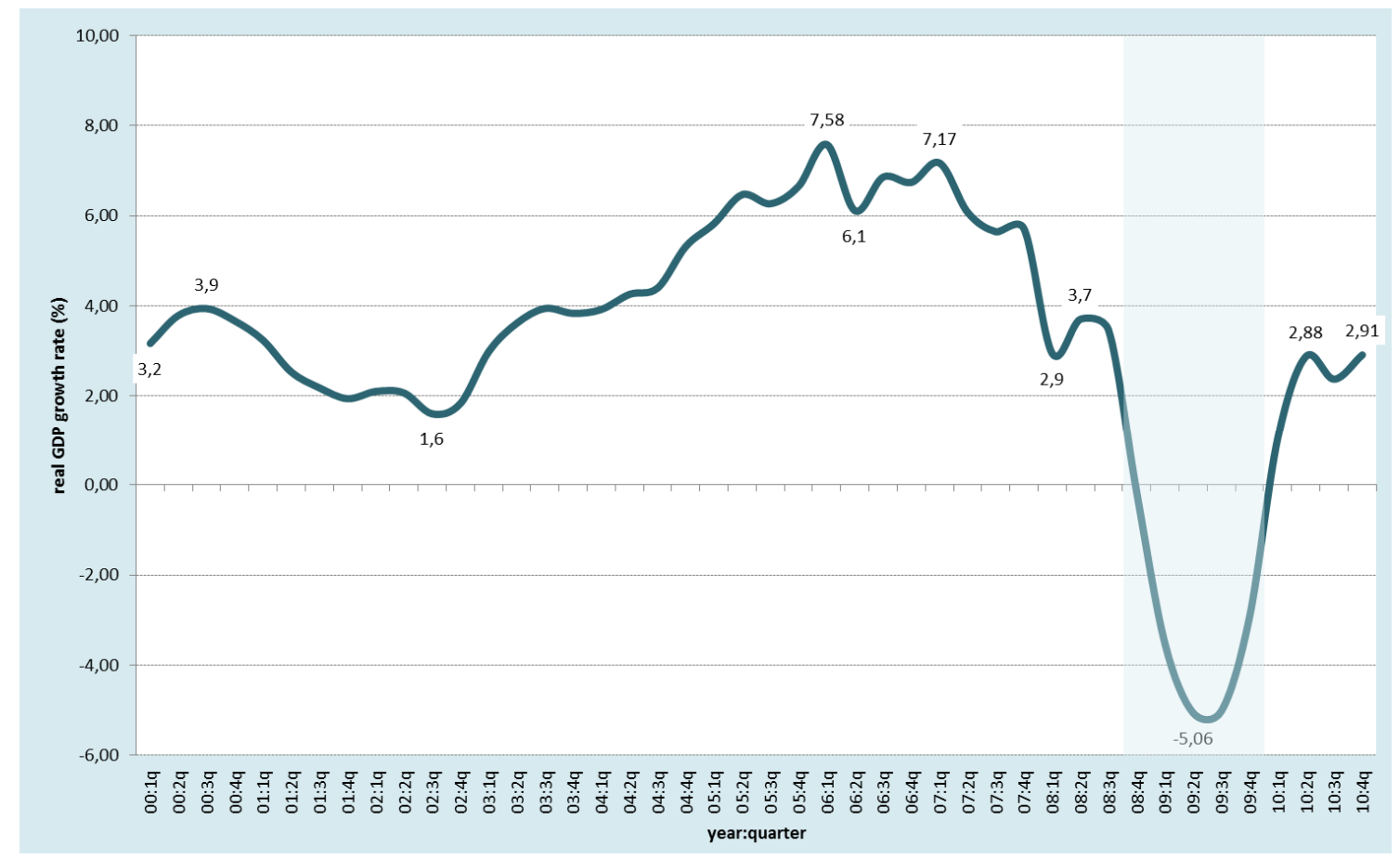

1: Real GDP growth (quarterly data, 2000-2010)

Source: Czech Statistical Office 
- the second phase that can be identified with the period since the 4Q 2008 and 4Q 2009, in which real GDP declined by 4.15\%. Spěváček and Vintrová (2010) argue that although the domestic financial sector was not hit by the global financial crisis, which was behind the downturn in economic activity in the euro area, expectations of economic agents worsened and, moreover, the economy was hit by strong external demand-shock.

As is evident from Figure 2, the GDP decline was mainly caused by weaken foreign trade which was negatively affected by unfavourable development in the euro area, especially in Germany. Its contribution to real GDP growth reached -2.85 percentage points in average in the first two quarters of the second phase. In this context, it should be also mentioned the problem of overly rapid appreciation of the Czech currency against world currencies (euro and US dollar) at the beginning of the financial and economic crisis (see Lacina and Toman, 2009) which reduced the competitiveness of Czech exports. It could be expressed by the real effective exchange rate (REER). On the other hand, the strong crown partially eliminated the sharp rise in oil prices on world markets. In 2009, the REER due to uncertainty in financial markets and the economic crises in major economies felt by 11 percent which had a positive impact on the competitiveness of the Czech exporters (Report IMF, 2010). Expenditures on net exports were followed by expenditures on gross fixed capital formation. Their contribution to GDP growth reached an average rate of $-1.52 \%$.
In seeking the causes of this decline we must focus on the financial sector. Although commercial banks were not much affected by the financial crisis, under the influence of particular problems in original EU15, they throttled credit channel to the corporate sector. The Czech Central Bank (CNB) tried to push along (like the ECB) investment incentives as the possible stimulus for growth of aggregate demand - a gradual reduction of the two week repo-rate was introduced. The rate felt to historical $0.75 \%$ at the beginning of 2010. Along with this fact, it is necessary to say that while in the case of foreign trade was recorded a positive turnover in the forthcoming quarters (foreign trade was the main driven force of GDP growth at the end of 2009 with its contribution of $3.07 \%$ ), in the case of gross fixed capital formation the development was entirely opposite. Expenditures on the acquisition of fixed assets, inventories and valuables can be marked as one of the causes of the Czech economy's decline. This argumentation is supported by statistical data, which show that during the period from $4 \mathrm{Q}$ 2008 to 4Q 2009 gross capital formation amounted contribution to GDP growth of -2.82 percentage points.

Low investment demand for the period from $4 \mathrm{Q}$ 2008 to 4Q of 2009, which reflects both the growing investor uncertainty about the future development of domestic and foreign demand and increased caution of banks in granting new loans, had negative symptoms in investment in machinery, equipment and vehicles. Uncertainty about the future development reflected on behaviour of households

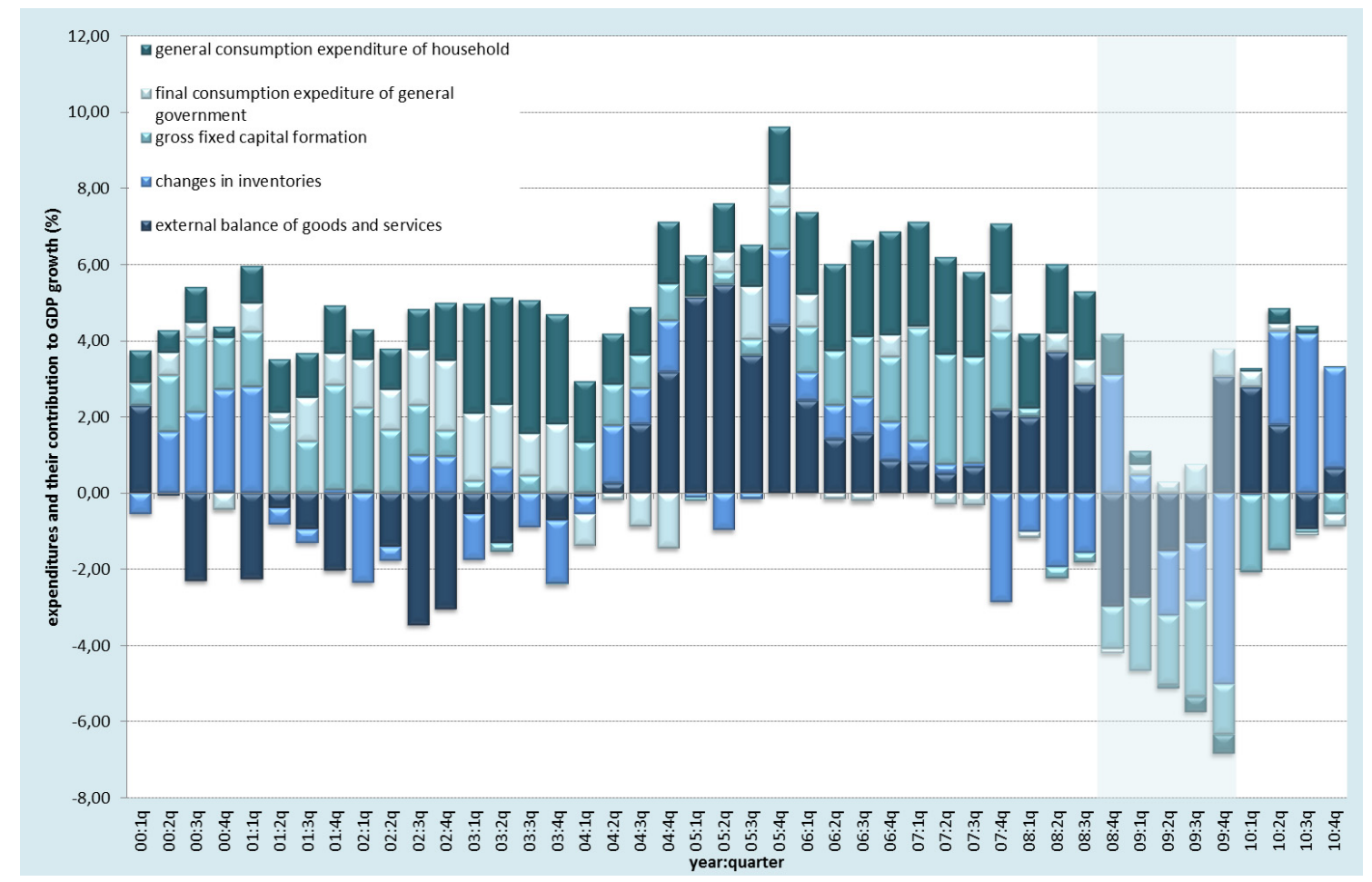

2: Expenditures and their contribution to GDP growth (quarterly data 2000-2010)

Source: Czech Statistical Office 
- that fall in their investment activities displayed their negative expectations about labour market performance. The slump in investment spending of households resulted primarily in the fall of housing investment.

Negative expectations associated with relatively weak aggregate demand and an uncertain scenario of recovery had considerable influence on the decline in stock volume (change in inventories decreased from original 10717 million CZK to -36 458 million CZK between 4Q 2008 and 4Q 2009). We have also seen a sustained fall in stocks of nonfinancial corporations and financial institutions in the last three quarters. As the result, the average contribution of this expenditure to GDP growth reached negative values and it has become the main brake for possible recovery in the last quarter of 2009. As mentioned above, it is clear that both the fall in foreign demand and domestic demand for investment had significant harmful impact on GDP growth.

If we focus our attention on the supply side of the economy, then we can conclude that the gross value added (GVA) reached average growth rate at $3.36 \%$ during the economic crisis (see Figure 3). Despite the decline in GVA accounted for nearly three fifths of all the observed sectors, we can say that the manufacturing contributed to the decrease in GVA most. In addition, this sector has a key influence on economic performance. The decline in manufacturing has been quite closely connected with the decline in foreign demand. It responded with a lag of one quarter when its minimum reached in the 2Q 2009, while foreign demand made the biggest slump in Q1 2009. Most notably, this decline occurred in the production of capital goods, whose production is generally largely intended for export, which is further confirmed by a relatively close relationship between foreign demand and manufacturing. Other sectors did not affect GVA as strong as manufacturing. If we look at our calculated data, the second sector which had remarkable impact on GVA was sector of trade, repair of motor vehicles and consumer goods. Other sectors with the indispensable impact on GVA were mining and quarrying industry, the real estate industry, services, research, development, production and distribution of electricity, gas and water. As is evident from the above, GVA was also negatively affected, except the industry, by the sector services.

A turnover in this negative development occurred at the beginning of 2010 - year-on-year real GDP growth of $1.03 \%$ was reached (based on preliminary data) and year-on-year growth of GVA reached the rate of $1.59 \%$. The value of these macroeconomic aggregates increased up by 2.05 , respectively $3.21 \%$ during the first nine months.

Prior an analysis of the economic crisis's impact on the Czech labour market, it seems to be appropriate to look at potential GDP as an indicator which is one of the key macroeconomic indicators. Central banks usually calculate potential output to estimate the output gap, which is used as one of the key indicators for decisions on interest rate changes. The output gap is defined as the percentage deviation of real output from its potential level. Real

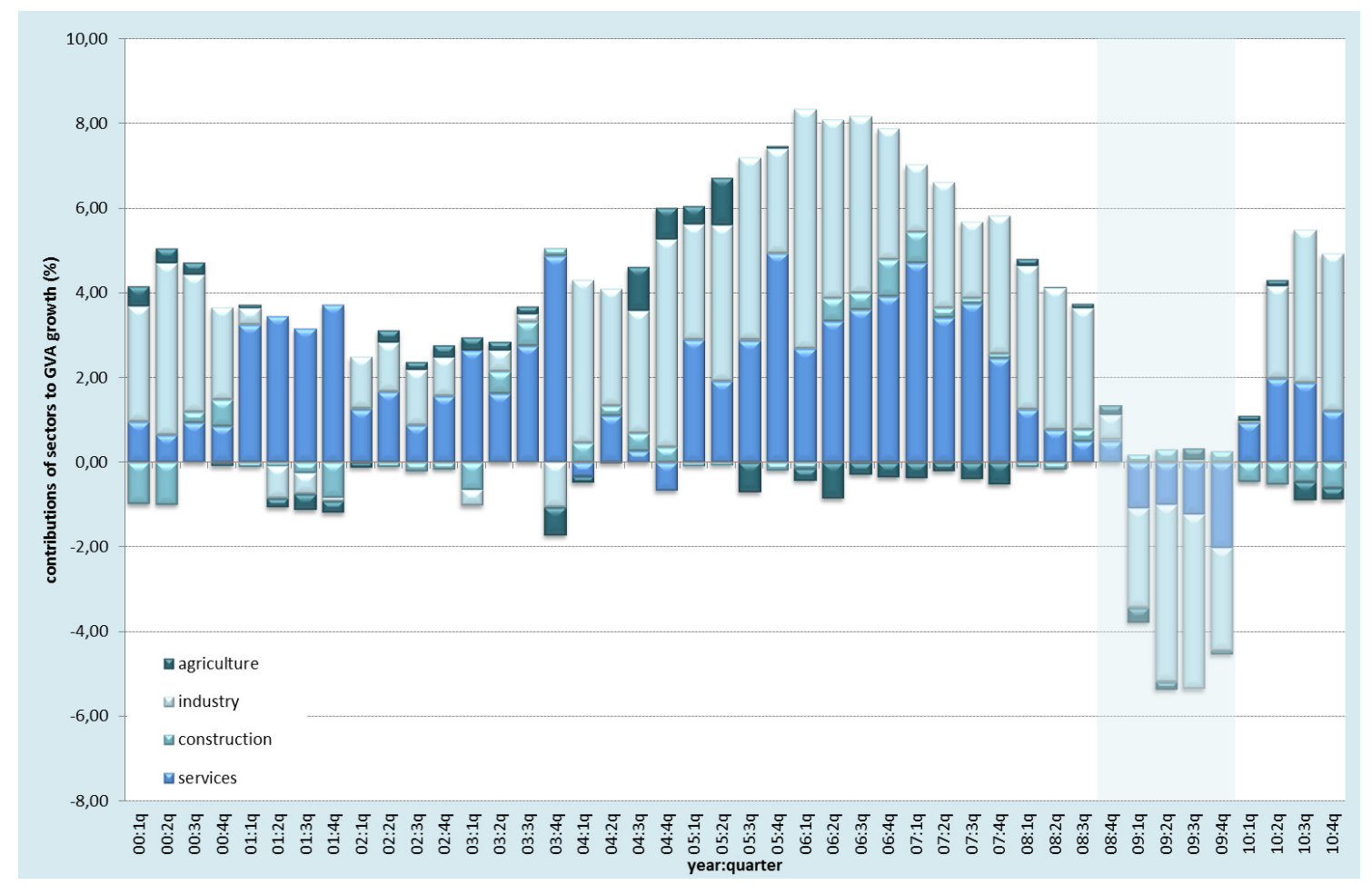

3: Contributions of sectors to GVA growth (quarterly data 2000-2010)

Source: Czech Statistical Office 
I: Potential and real gross domestic product and output gap of the Czech economy 2000-2009 (mil. CZK, c.p. of 2000, \%)

\begin{tabular}{lcccccccccc}
\hline & $\mathbf{2 0 0 0}$ & $\mathbf{2 0 0 1}$ & $\mathbf{2 0 0 2}$ & $\mathbf{2 0 0 3}$ & $\mathbf{2 0 0 4}$ & $\mathbf{2 0 0 5}$ & $\mathbf{2 0 0 6}$ & $\mathbf{2 0 0 7}$ & $\mathbf{2 0 0 8}$ & $\mathbf{2 0 0 9}$ \\
\hline GDP $_{\mathbf{r}}$ & 2191.3 & 2244.9 & 2286.0 & 2368.4 & 2470.8 & 2628.5 & 2812.2 & 2984.7 & 3053.3 & 2930.6 \\
GDP $_{\mathbf{p}}$ & 2176.2 & 2235.1 & 2311.1 & 2406.9 & 2521.8 & 2648.6 & 2773.3 & 2879.5 & 2956.9 & 3010.5 \\
GAP & 0.69 & 0.44 & -1.10 & -1.63 & -2.06 & -0.77 & 1.38 & 3.53 & 3.15 & -2.73 \\
\hline
\end{tabular}

Source: Own calculation based on Eurostat data

output gap is not only a commonly used indicator of the economy's position in the business cycle, but is also a key indicator of inflationary pressures on the demand size of the economy (see Hloušek and Polanský (2007) or Hájek and Bezděk (2001)). We can say that with the help of this macroeconomic indicator we are able to better identify the different phases of the economic cycle, and thus we can better understand of the events that have occurred during observed period.

The output gap is defined as $\left(\mathrm{Y}-\mathrm{Y}^{*}\right) / \mathrm{Y}^{*}$, where $\mathrm{Y}$ is real GDP and $\mathrm{Y} *$ is potential GDP.

We applied the Hodrick-Prescott filter (HP filter) for estimation potential GDP. This method is quite frequently used to filter the trend and the cyclical time series. To estimate potential output, it is necessary to have just the time series of real GDP. The only input parameter for the optimal filter, we have to specify, is an appropriate smoothing constant $\lambda$. It is defined as the ratio of dispersion of shock causing cyclical fluctuations and shocks affecting the growth trend (Hloušek and Polanský (2007)).

The filter is characterized by this formula (Hájek and Bezděk (2001)):

$\operatorname{Min}\left\{\sum_{t=1}^{T}\left(\ln Y_{t}-\ln Y_{t}^{*}\right)^{2}+\lambda \sum_{t=2}^{T-1}\left[\left(\ln Y_{t+1}^{*}-\ln Y_{t}^{*}\right)-\left(\ln Y_{t}^{*}-\ln Y_{t-1}^{*}\right)\right]\right\}$,

where $\mathrm{Y}$ denotes the real output, $\mathrm{Y}^{*}$ is potential output, $\lambda$ is a parameter determining the smoothness of the trend smoothing. For $\lambda=0$ potential output is equal to real GDP, for $\lambda \rightarrow \infty$ the trend will be a straight line.

When choosing a value of smoothing constant $\lambda$, we then drew on generally accepted recommendations - experts consider optimal value 1600 for quarterly data and 100 for annual data (Rozmahel, 2011, OECD, 1995, Gerlach and Yiu, 2004 or Hájek and Bezděk, 2001).

As is evident from the data captured in before the crisis of the real economy, the Czech economy was in a relatively strong inflation gap (see calculated values of an output gap in Table I). According to estimated data values of real output exceeded values of potential output, which clearly shows that the Czech economy used production factors with too much intensity during this period. It was untenable from the long-run view.

\section{Impacts of the crisis on the Czech labour market}

If we accept these findings and use them as a basic for explaining changes in the labour market, then it can be assumed that the labour force was exploited too much in the period between IQ 2006 and 3Q 2008. Expressed by macroeconomic indicators, this means the increase of the employment rate and the decrease of the unemployment rate (see Figure 4) which should be below the natural rate of unemployment. Our conclusion was confirmed by the estimated natural rate of unemployment $\left(u^{*}\right)$. According to Blanchard and Katz (1996) the natural rate of unemployment is typically interpreted as the rate of unemployment consistent with constant (non-accelerating) inflation. Then the difference between the estimated natural rate of unemployment and the unemployment rate is unemployment gap. Any decline in aggregate demand will increase the actual rate of unemployment, while an expansion of aggregate demand will lower the actual rate of unemployment. However, in the long run, unemployment returns to the natural rate of unemployment (Snowdon and Vane, 2005), in other words it means that the labour market is in steady-state. We again performed calculation using the HP filter on seasonally adjusted data as it was performed in da Silva Filho (2010). Obtained data show the development of the Czech labour market (see Table II). Based on these estimates, we believe that the real unemployment rate, with the exception of 2006, was consistently below the natural rate of unemployment during this period. The most obvious differences between these two rates can be seen in 3Q and 4Q 2008, when the difference between the real and the natural rate of unemployment reached 1.40, 1.26 percentage point, respectively.

The data contained in Tables I and II show that the labour market development is closely linked to economic performance of the Czech Republic, as in other advanced economies. A decline in real GDP growth was accompanied by a rise in the unemployment rate between 4Q 2008 and 4Q 2009. Moreover, this macroeconomic indicator responded to the change of economic performance with a lag (around one quarter).

Looking at the Czech labour market, then we can assume that its development over the past fifteen years was influenced by many factors. The first factor is the restructuring process of the economy that is closely linked to the emergence of highly competitive market environment, 
which was followed by necessary rationalization of manufacturing operations. Another factor is volatility of economic performance, which played a key role in the case of the Czech economy as well as in the case of major trading partners' economies. The influence of these factors on the Czech labour market were reflected not only in the cumulative decline in the employment rate by $0.39 \%$ (in absolute terms the number of employed dropped by 31.78 thousand persons). But much more perceptible change was the increase of the unemployment rate. Expressed in absolute term, it means that the total number of unemployed increased by 152.27 thousand persons. Quite a massive rise in unemployment was, in our view, associated primarily with changes in the structure of the Czech economy as evidenced by the qualification structure of unemployed, the high share of long-term unemployed in the total unemployment and last but not least, regional differences in unemployment are directly associated with former structure of the economy in some specific regions.

In the past decade, the Czech labour market has undergone quite a dramatic development, resulting in an increase in the unemployment rate from the original 9.51\% in Q1 2000 to 7.09\% in 3Q 2010. Generally, we can identify five main phases in the period 2000-2010:

- In the first phase (1Q 2000 to $2 Q$ 2002) the unemployment rate decreased to a level of $6.98 \%$. As the main factor could be marked inflows of foreign direct investment to the Czech Republic.

- Inthe second phase, increase in the unemployment rate was renewed and it peaked in 1Q 2004.

- With the Czech Republic's accession into the European Union is associated the third phase. The unemployment rate decreased from $8.67 \%$ to $4.28 \%$ in 3Q 2008.

- The fourth phase started at the end of 2008, in which unemployment was greatly influenced by the economic crisis. The unemployment rate increased significantly during the six quarters (the increase by $3.76 \%$ ).

- According to the latest available data, this phase was replaced by the last, fifth one, which is connected first with a relatively sharp decline in the unemployment rate and subsequent stagnation around $7 \%$.

Given the limited extent of this paper, paper does not deal with labour market performance in the first

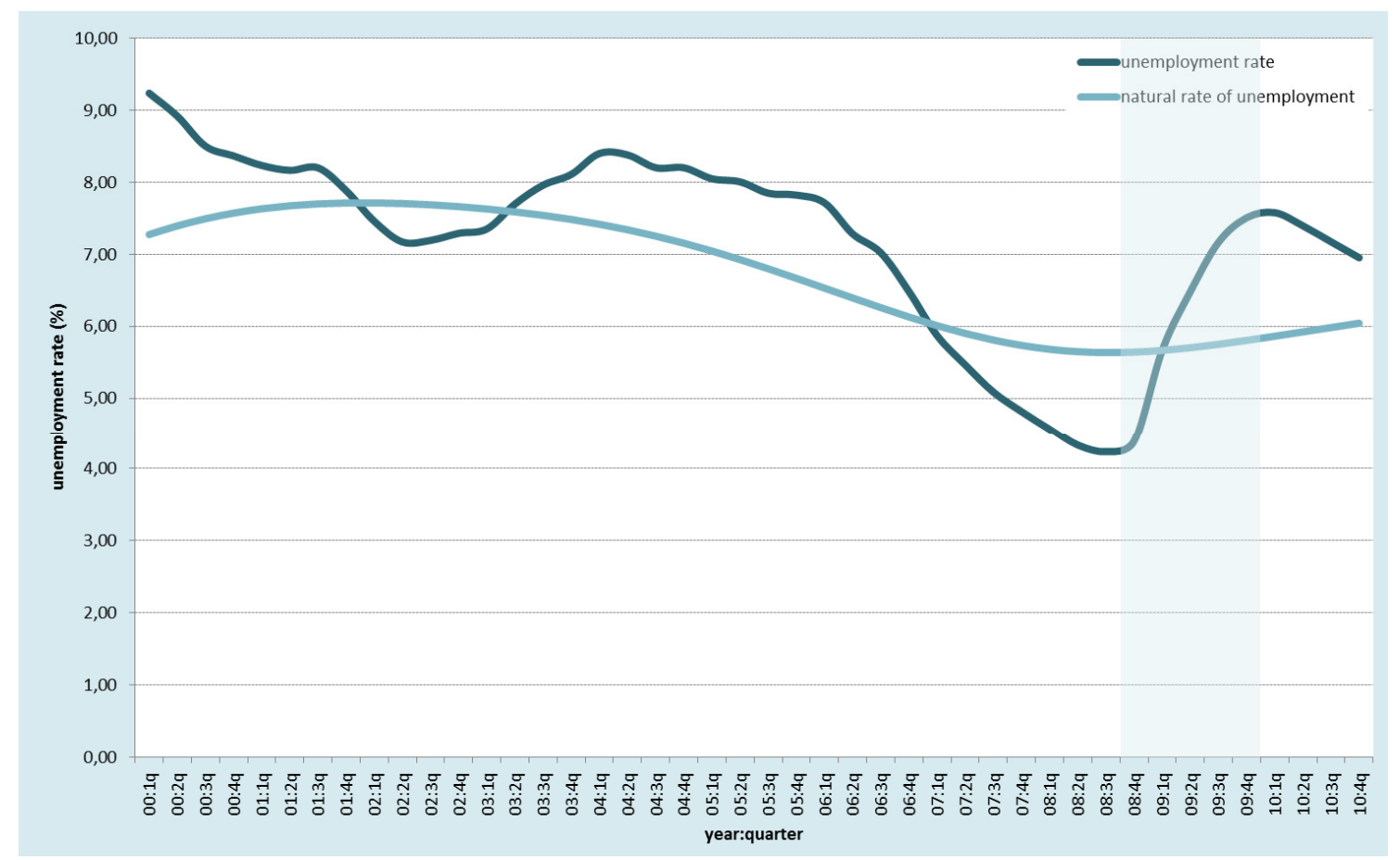

4: Unemployment rates (quarterly data, 2000-2010)

Source: Czech Statistical Office

II: Natural rate of unemployment in the Czech economy 2000-2009 (\%)

\begin{tabular}{lcccccccccc}
\hline & $\mathbf{2 0 0 0}$ & $\mathbf{2 0 0 1}$ & $\mathbf{2 0 0 2}$ & $\mathbf{2 0 0 3}$ & $\mathbf{2 0 0 4}$ & $\mathbf{2 0 0 5}$ & $\mathbf{2 0 0 6}$ & $\mathbf{2 0 0 7}$ & $\mathbf{2 0 0 8}$ & $\mathbf{2 0 0 9}$ \\
\hline $\mathbf{u}$ & 8.12 & 7.28 & 7.78 & 8.30 & 7.93 & 7.13 & 5.31 & 4.38 & 6.71 & 7.28 \\
$\mathbf{u}^{*}$ & 7.68 & 7.69 & 7.56 & 7.29 & 6.86 & 6.33 & 5.86 & 5.65 & 5.73 & 5.95 \\
GAP & 0.44 & -0.41 & 0.22 & 1.00 & 1.07 & 0.80 & -0.55 & -1.27 & 0.98 & 1.32 \\
\hline
\end{tabular}

Source: Own calculation based on Eurostat data 
three stages in detail. Our attention goes straight to the fourth phase. During this period, it has begun to show a significant discrepancy between quantity of labour supply and labour demand, which consequently resulted in a relatively sharp rise in the unemployment rate. As a result of these developments, re-widening of regional disparities occurred in unemployment levels (traditionally the lowest unemployment rate existed in the region of the capital city, while the highest unemployment rate was found in Karlovarský region).

In terms of economic activity, lower economic performance was most notable among male labour force - a significantly lower share of economically active persons in the age group of 55-64 years of age (decrease of 15.43\%) and reduced economic activity of men with secondary education without leaving examination (decrease of $9.75 \%$ ). In the case of women, economic activity felt in the age group 20 to 24 years of age (decrease of 4.65 percentage points). Most vulnerable group consists of young people less than thirty years of age with primary or secondary education without graduation.

Looking at the development of the unemployment rate according to the genders no significant differences between unemployment rates among men and women have been registered. The only conclusion, we argue based on available data, is that the crisis had slightly greater impact on unemployment among the male labour force. This can be partly explained by the fact that the main brake of economy's recovery is considered the industry in which two-thirds of the male labour force is employed.

In addition, we can say that in both absolute and relative terms, the decline in economic performance had the most remarkable impact on manufacturing - in 1Q 2010 by 293.33 thousand employees less were employed in comparison with 3Q 2008. It means that in a given sector, total employment felt by $16.47 \%$. On contrary, labour productivity increased at the same time by $10.24 \%$. Based on data, it is clear that the secondary sector's ability to absorb the economically active population disappeared in 2009. On the contrary, the tertiary sector absorbed 30.53 thousand people.

A relatively sharp decline in the share of longterm unemployment in total unemployment is another striking feature. While in 3Q 2008 the share of unemployed who were looking for a job for more than one year was less than fifty percent in total unemployed, six quarters later, this share was 12.80 percentage points lower and amounted to "only" $35.62 \%$. At first glance, it may appear that the decline in economic performance significantly improved the situation long-termed unemployed. But such an interpretation it would be very misleading since the decline of long-term unemployment was not due to decrease in the number of applicants seeking jobs for more than one year (numerator), but contrast, the overall increase in the total number of the labour force without a job (the denominator).
In addition, as a consequence, a certain number of unemployed has begun to gradually move into the category of long-term unemployed (the numerator of the denominator), which subsequently resulted in the re-growth in the share of long-term unemployment in total unemployment.

Long-term unemployment, analogous to total unemployment, fluctuates consistent with a phases of the business cycle in the most countries. In addition Abraham and shimer (2001) mention that at the most of proceeded economic cycles it was proved rather strong correlation between the unemployment level and average duration of unemployment. Besides, there is an interesting fact that the persistence of unemployment did not decrease after the economic recession in such intensity as in the case of a decrease of the unemployment rate. OECD study (1993) even declares that long-term unemployment tends to grow for a year or two since the beginning of decreasing of unemployment and afterwards it starts to decline slowly. The fundamental question than is, which factors cause a delayed reaction of longterm unemployment (in the sense of its decreasing) after subsiding of a shock. The study explains this phenomenon through the dynamics of the labour market, which is a function of speed recovery of the market, a degree of structural changes taking place in the economy. In addition it could be the setting of various government programmes assisting unemployed people and finally it is also the amount of previous short-term unemployed finding a new job.

In this context it should be noted that duration of unemployment may have a negative impact on a restoring macroeconomic equilibrium. Pissarides (1992: 1371-1372) assumes existence of a negative shock which could have effect on employment firms will be wary, based on uncertain expectations about future, and they will hire fewer workers. This will also prolong the duration of unemployment. If the long-term unemployed lose their knowledge and skills and thus they become less attractive for their potential employers, the results of this phenomenon will be that there will be created fewer jobs and the labour market becomes "tight" for the reason of a lower human capital brought by the labour force as the whole. With the number of offered jobs, which is lower than usually, it also increases duration of unemployment of the new group of unemployed above a trend level. This is the reason why the labour market remains tight in the future and even if all the labour force, which had been in the previous period (before the shock) unemployed, would have attained a job. The tight labour market leads to a greater lack of work, which causes maintenance of the tightness of the labour market. Thus the effects of a negative shock persist and if the externality is strong enough, than the economy can "get stuck" on the lower macroeconomic equilibrium level.

The adverse situation in the Czech labour market can be described by another indicator - job vacancy statistics which provides information on unmet labour demand (unfilled jobs or in other words the number of applicants per one job vacancy). While 
in 3Q 2008 the value of this indicator felt to historic minimum in the last eleven years, in 1Q 2010 it reached its historic maximum, when a number of unemployed on one job vacancy accounted for nearly eighteen.

This negative trend can also use it to document the Beveridge curve (BC) which is a graphical representation of the relationship between unemployment and the job vacancy rate (the number of unfilled jobs expressed as a proportion of the labor force). It typically has vacancies on the vertical axis and unemployment on the horizontal; it slopes downwards as a higher rate of unemployment normally occurs with a lower rate of vacancies. If it moves outwards over time, then a given level of vacancies would be associated with higher and higher levels of unemployment, which would imply decreasing efficiency in the labour market. Inefficient labour markets are due to mismatches between available jobs and the unemployed and an immobile labour force (Bleakley and Fuhrer, 1997).

The inefficiency of labour market performance is due to job mismatches. Position on the curve can indicate the current state of the economy. In practice, it means that if we find the curve below the axis of 45 degrees, the economy generally is in a recession (the high unemployment rate and low levels of job vacancies). On the contrary, position above the axis of 45 degrees indicates phase of economic growth (low unemployment rate and high job vacancy rate). Development of the Czech labor market most closely matches theoretical construction of the Beveridge curve (see Figure 5).

The initial quarter (1Q2000) was characterized by the high unemployment rate and low level of unfilled jobs. The figure shows that the Czech labour market has undergone two cycles during the observed period. The first cycle occurred between 2000 and 2004, the second one occurred from 2006 to 2010. Each cycle started by gradual improvement in the labour market. This trend was reflected by reducing unemployment and raising the number of unfilled jobs. In the next phase, after reaching the summit, unemployment started to grow and the number of unfilled jobs started to decline as the consequences of the economic crisis. The fundamental difference between these two cycles consisted of dynamics. While in the first cycle, shifts of the Beveridge curve were minor, there were significant shifts during the second cycle.

In the context of this analysis, we also seem appropriate to briefly consider the development of wages and labour productivity. As stated above between 3Q 2008 and 1Q 2010 real GDP felt cumulatively by $8.70 \%$, while total employment rate felt by only 3.70 percentage points. From that it is clear that the GDP decline was largely associated with the decrease of labour productivity. Adverse situation is also evident from the ratio of cumulative aggregate growth of labour productivity (-3.26\%) and cumulative growth of real gross monthly wages (0.24\%). As the result, a relatively high increase of wage costs was recorded (3.5 percentage points).

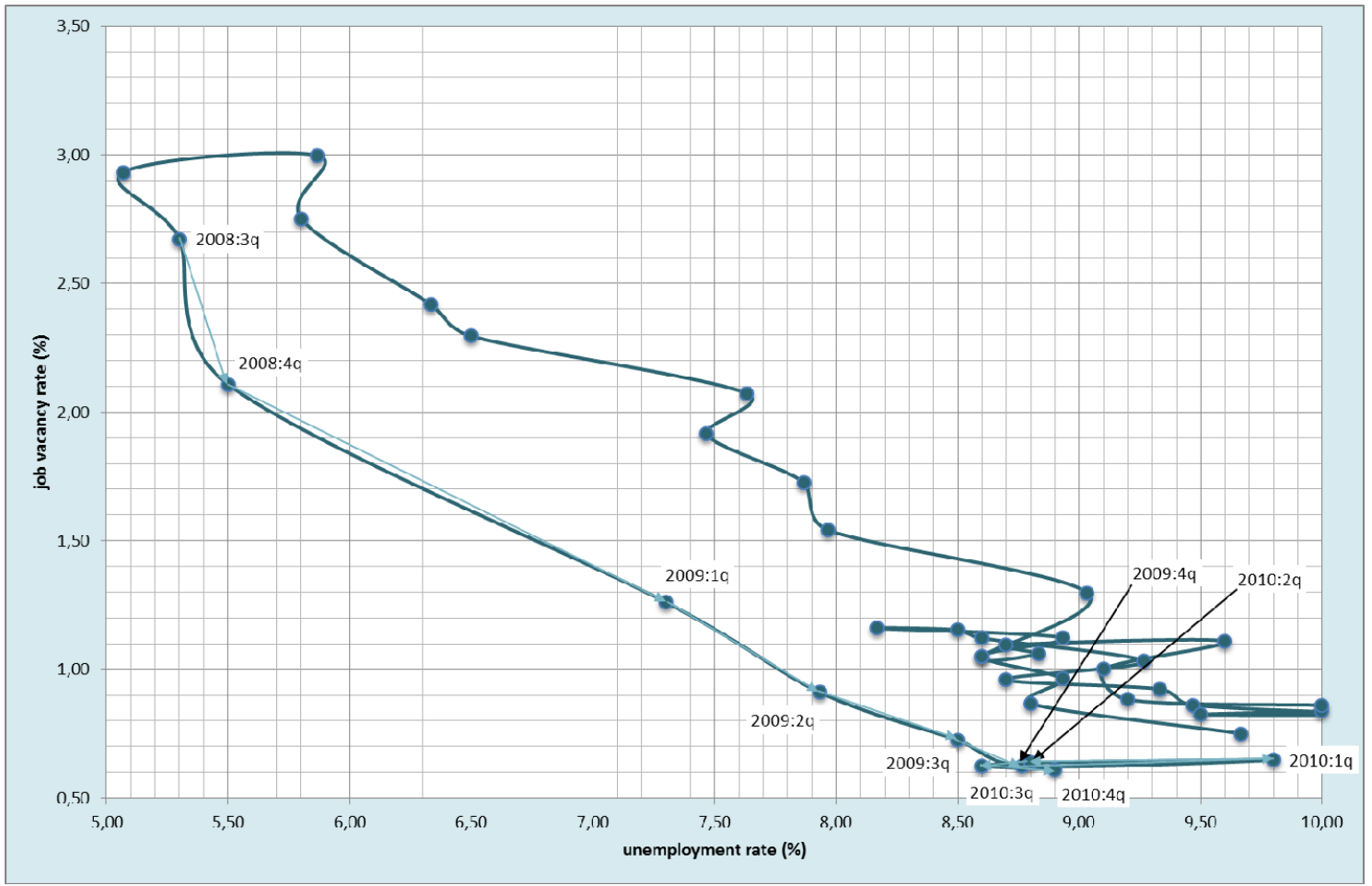

5: Beveridge curve for the Czech Republic (quarterly data, 2000-2010) Source: OECD 


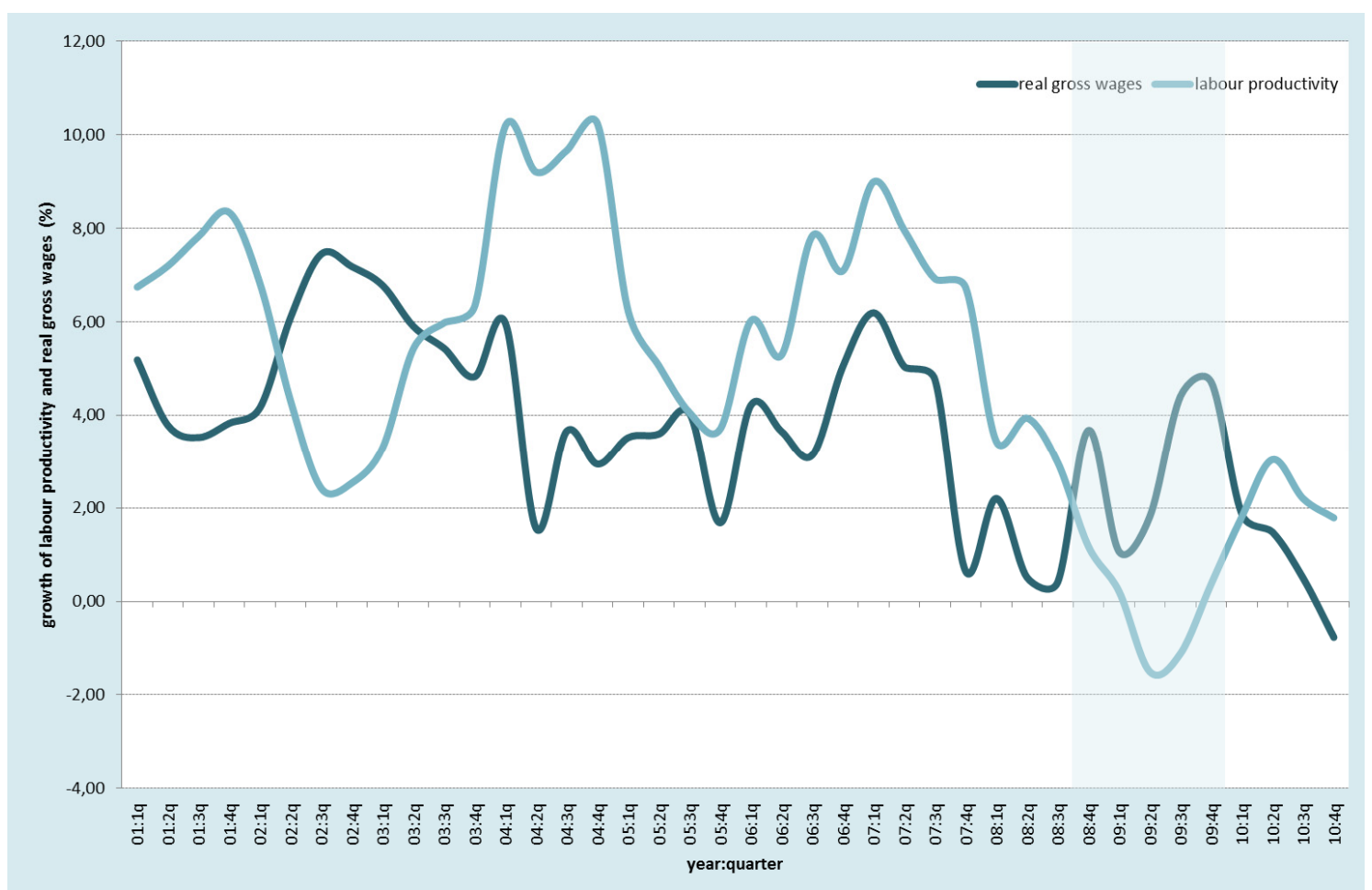

6: Growth of labour productivity and real gross wages (quarterly data, 2001-2010)

Source: Czech Statistical Office

One question remains - a source of this growth. According to the analysis of the Czech Statistical Office (2010), we could argue that the source of this development was average nominal wage growth during 2009, influenced by lower sickness absence and shifts in employment structure, since the economic downturn did not have symmetric impact on male and female labour force, age groups and types of contracts. During the economic crisis, mainly employees with lower earnings or with above-average sickness absence were fired, which resulted in growth of average wages. We can find some factors which contributed to reduce sickness absence, such as introducing initial three-day period without sick pay, replacement sickness leave by taking vacation, and general fear of losing a job (CNB, 2010).

\section{CONCLUSION}

Our main research task was to answer the question mentioned in introduction. If we use our previous partial conclusions, then we argue that the decline of economic performance directed the Czech labour market on the road to return to a state of long-term equilibrium. This argumentation may seem at least controversial, but if we look at the situation before the outbreak of the economic crisis, then we can see that the Czech economy was in a relatively strong expansion and it was found in the inflation gap (real GDP exceeded potential GDP). This resulted in usage the production factors (especially labour) with the too much intensity in the Czech
Republic, and it was untenable in the long-run view. It had to be logically reflected in labour market performance in the sense that in the first half of 2008, calculated according to our data, the number of employees exceeded its long-term average, and the unemployment rate was below its natural rate. For this fact also speaks very close approximation of labour demand and labour supply, which occurred from early 2006 to $3 Q$ 2008. If we understand these indicators in the context of above mentioned events, then we come to unambiguous conclusion. It suggests that the Czech labour market had to cope with the consequences of the economic crisis and now it is going to reach a long-term equilibrium. This argumentation is supported, to some extent, by data for the 2Q and 3Q 2010, which shows that the actual unemployment rate is converging to the natural rate of unemployment which will lead to gradual elimination of some negative phenomena, which is to promote the labour market in the previous six quarters. Exports slumps were among main negative factors which have influenced the Czech labour market. A decline in orders and growth of stocks and inventories has led to firing workers and significantly lower job creation. Large uncertainty about future development had also remarkable impact on both aggregate demand and supply. In addition, employers were more reluctant to hire workers even economic performance has improved. 


\section{SUMMARY}

The aim of this paper is to examine factors of the economic crisis in the Czech economy and its effects on the labour market during the period 2000-2010. We also tried to contribute to discussion about consequences of this crisis. The paper provides also an analysis of gross domestic product and its components. The empirical analysis also tried to answer the question if it is more a return to steadystate than the deterioration of economic performance in the case of the Czech economy. In other words, it means that economic performance of the Czech economy was above the level of potential output. We applied the Hodrick-Prescott filter (HP filter) for estimation potential GDP. This method is quite frequently used to filter the trend and the cyclical time series. Research in this study is based on basic macroeconomic quarterly data between the years 2000 and 2010 which were published by the Czech Statistical Office and Eurostat. As is evident from the data captured in before the crisis of the real economy, the Czech economy was in a relatively strong inflation gap. We argue that the decline of economic performance directed the Czech labour market on the road to return to a state of long-term equilibrium. This argumentation may seem at least controversial, but if we look at the situation before the outbreak of the economic crisis, then we can see that the Czech economy was in a relatively strong expansion and it was found in the inflation gap (real GDP exceeded potential GDP). This resulted in usage the production factors (especially labour) with the too much intensity in the Czech Republic, and it was untenable in the long-run view. We found out the difference between the estimated natural rate of unemployment and the unemployment rate which is called an unemployment gap. During the last period, it has begun to show a significant discrepancy between quantity of labour supply and labour demand, which consequently resulted in a relatively sharp rise in the unemployment rate. In addition, development of the Czech labor market most closely matches theoretical construction of the Beveridge curve.

\section{Acknowledgement}

The research behind this paper was partly supported by the Czech Science Foundation within the project GAČR 402/09/P142 "Institutional labour market framework in the context of economic convergence and adopting single currency (application on Visegrad group countries)".

\section{REFERENCES}

ABRAHAM, K. G., SHIMER, R., 2001: Changes in Unemployment Duration and Labor Force Attachement. NBER Working Paper No. 8513. [online] [cit. 2011-01-19] Available from <http:// www.nber.org/papers/w8513>.

BLANCHARD, O., KATZ, L. F., 1996: What we know and do not know about the natural rate of unemployment. NBER Working Paper No. 5822. [online] [cit. 2011-04-20] Available from <http:// www.nber.org/papers/w5822>.

BLEAKLEY, H., FUHRER, J. C., 1997: Shifts in the Beveridge Curve, Job Matching, and Labor Market Dynamics. New England Economic Review: 1997. [online] [cit.2011-03-12] Available from <http:// www.bos.frb.org/economic/neer/neer1997/ neer597a.pdf $>$.

CZECH NATIONAL BANK, 2010: Inflation report I/2010. [online] [cit. 2011-01-19] Available from <http://www.cnb.cz/miranda2/export/sites/ www.cnb.cz/en/monetary_policy/inflation reports/2010/2010_I/download/ir_I_2010.pdf >.

CZECH STATISTICAL OFFICE, 2010:Trh práce v ČR 1993 až 2009. [online][cit. 2011-01-25] Available from <http://www.czso.cz/csu/2010edicniplan. nsf/p/3103-10 >.

CZECH STATISTICAL OFFICE, 2010: Zaměstnanost a nezaměstnanost v ČR podle výsledků výběrového šetření pracovních sil. [online] [cit. 2011-
02-10] Available from <http://www.czso.cz/csu/ 2010edicniplan.nsf/p/3101-10>.

FERNANDEZ, A. Z., NIKOLSKO-RZHEVSKYY, A., 2010: The changing nature of the U.S. economic influence in the World. Journal of Policy Modeling, 32, 2, 196-209.

GERLACH, S., YIUN, M. S., 2004: Estimating output gaps in Asia: A cross-country study. Journal of Japanese and International Economies, 18, 1, 115-136.

HÁJEK, M., BEZDĚK, V., 2001: Odhad potencionálního produktu a produkční mezery v České republice. Politická ekonomie, 50, 4, 473-491.

HLOUŠEK, M., POLANSKÝ, J., 2007: Produkční přístup $\mathrm{k}$ odhadu potenciálního produktu aplikace pro ČR. Národohospodárský obzor, 7, 4, 3-12. ISSN 1213-2446.

IMF, 2010: Czech. Czech Republic: Staff Report for the 2010 Article IV Consultation. IMF Country Report No. 10/60. [online][cit.2010/05/14] Available from <http://www.imf.org/external/ pubs/ft/scr/2010/cr1060.pdf $>$.

LACINA, L., TOMAN, P., 2009: Je plovoucí kurz měny výhodou $\mathrm{v}$ období finanční a ekonomické krize? Národohospodář́ský obzor, 9, 4, 196-211. ISSN 1213-2446.

OECD, 1993: OECD Employment Outlook 1993 [online]. Paris: OECD [cit. 2011-0125]. Available from <http://www.oecd.org/ dataoecd/59/22/2485426.pdf $>$. 
PISSARIDES, CH. A., 1992: Loss of Skills During Unemployment and the Persistence of Employment Shocks. The Quartely Journal of Economics, 107, 4, 1371-1391. ISSN 1531-4650.

PWC, 2010: Report on Transformation. Hard Landing [online][cit.2011/02/12] Available from <http://www.pwc.com/en_CZ/cz/tiskovezpravy-2009/hard-landing-report.pdf $>$.

ROZMAHEL, P., 2011: Measuring the business cycles similarity and convergence trends in the Central and Eastern European Countries towards the Eurozone with respect to some unclear methodological aspects. Acta Universitatis Agriculturae et Silviculturae Mendelianae Brunensis. 59, 2, 237-250.

SILVA FILHO da, T., N., T., 2010: The Natural Rate of Unemployment in Brazil, Chile, Colombia and
Venezuela: some results and challenges. Banco Central do Brasil Working Paper Series No.212. [online][cit.2011/04/12] Available from <http:// www.bcb.gov.br/pec/wps/ingl/wps212.pdf $>$.

SNOWDON, B., VANE, H. R., 2005: Modern Macroeconomics. Cheltenham: Edward Elgar.

SPĚVÁČEK, V., VINTROVÁ, R., 2010: Růst, stabilita a konvergence české ekonomiky v letech 20012008. Politická ekonomie, 59, 1, 20-50. ISSN 00323233.

VINTROVÁ, R., 2008: Česká a slovenská ekonomika 15 let po rozdělení. Politická ekonomie, 56, 4, 449-466. ISSN 0032-3233.

doc. Ing. Pavel Tuleja, Ph.D., Mgr. Ing. Michal Tvrdoň, Ph.D., Slezská univerzita, Obchodně podnikatelská fakulta, Katedra ekonomie, Univerzitní nám. 1934/3, 73340 Karviná, Česká republika, e-mail: tuleja@opf. slu.cz, tvrdon@opf.slu.cz 
